\title{
Tobacco Leaf Protein: I. \\ An Evaluation of the Use of Putative Chemical Growth Enhancers for Tobacco Leaf Protein Production*
}

\author{
by \\ Donald W. De Jong \\ United States Department of Agriculture, \\ Agricultural Research Service, \\ Crops Research Laboratory, \\ Oxford, North Carolina, U.S. A.**
}

\section{SUMMARY}

Effects of foliar applications of long-chain fatty compounds on production of leaf protein from tobacco genotypes were evaluated. Triacontanol, purported to be a growth stimulant, had minimal effects on most experimental parameters. A propriety product, AgroLizer ${ }^{\mathrm{TM}}$, appeared to exert greater influence but results were inconclusive. Chemical treatments interacted with environmental conditions and tobacco genotype. Acid precipitation of the green fraction resulted in a pellet that could be easily removed by low speed centrifugation but produced a white fraction with lower protein percentage than heat precipitation of the green fraction. Triacontanol delayed flowering and extended vegetative growth in some genotypes. Increased cured leaf yields of flue-cured and Maryland type tobaccos were consistent but not statistically significant. An important finding was discovery of a genotype, T.I. 401, that produced high amounts of extractable leaf protein regardless of growth stage. This variety became the object of a follow-up investigation.

\section{ZUSAMMENFASSUNG}

Es wurden langkettige, aliphatische Verbindungen auf das Blattgut der Tabakpflanze aufgesprüht und die Auswir-

\footnotetext{
" Received: 27th March 1989 - accepted: 13th February 1990.

: The work reported here was conducted while the author was with the Tobacco Laboratory, Beltsville Agricultural Research Center.

Mention of a trademark or proprietary product does not constitute a guarantee or warranty of the product by the U.S. Department of Agriculture and does not imply its approval to the exclusion of other products that may also be suitable.
}

kungen auf die Produktion von Blattprotein bei verschiedenen Genotypen der Tabakpflanze bestimmt. Triacontanol, eine Substanz, welcher wachstumsfördernde Eigenschaften zugeschrieben werden, zeigte minimale Auswirkungen auf die Mehrzahl der experimentellen Parameter. Ein Markenprodukt, AgroLizer ${ }^{\mathrm{TM}}$, schien einen größeren Einfluß zu haben, die Ergebnisse waren jedoch unstimmig. Die chemische Behandlung, die äußeren Bedingungen und der Genotyp beeinflußten sich wechselseitig. Die Säurefällung der grünen Fraktion führte zu einem Pellet, das durch langsames Zentrifugieren leicht entfernt werden konnte; es entstand jedoch eine weiße Fraktion mit einem geringeren Proteingehalt als der, der bei der Wärmefällung der grünen Fraktion erzielt wurde. Triacontanol verzögerte bei einigen Genotypen die Blütenbildung und förderte das vegetative Wachstum. Der Proteingehalt der getrockneten Tabakblätter einiger flue-cured und Maryland-Tabake war dauerhaft erhöht, jedoch nicht signifikant. Von Bedeutung war die Entdeckung des Genotyps T.I. 401, der unabhängig vom Wachstumsstadium große Mengen extrahierbaren Blattproteins bildete. Diese Varietät wurde in einer nachfolgenden Studie untersucht.

\section{RESUME}

Ce travail porte sur l'évaluation des effets d'applications foliaires de composés aliphatique à longue chaîne sur la production de protéines foliaires de plusieurs génotypes du tabac. Triacontanol, substance dont on estime qu'elle 
favorise la croissance, a un effet minime sur la plupart des paramètres examinés. Un produit de marque, AgroLizer $^{\mathrm{TM}}$, semblait exercer une influence plus importante, mais les résultats obtenus n'étaient pas concluant. Le traitement chimique interagissait avec les conditions de culture et les génotypes du tabac. La précipitation à l'acide de la fraction verte conduisait à un culot, qui pouvait facilement être éliminé par une centrifugation à basse vitesse. Une fraction blanche était obtenue, dont la teneur en protéines était moins importante que celle résultant de la précipitation à chaleur de la fraction verte. Triacontanol a retardé la floraison et favorisé la croissance végétale de certains génotypes. L'augmentation du contenu élevé en protéines des feuilles séchées de certains types de tabacs flue-cured et Maryland était constante mais non significative. Un progrès important fut la découverte du génotype T.I. 401, qui produit de grandes quantités de protéines foliaires extractibles et ce indépendamment du stade végétatif. Cette variété est devenu l'objet de recherches plus poussées.

\section{INTRODUCTION}

Protein yield variability has been a major impediment to the development of reliable methods for commercializing protein production from tobacco leaves. Earlier work from this laboratory showed that total protein concentrations in freshly harvested green leaves from tobacco fluctuate in a saw-tooth pattern during plant development (1). Other investigators have commented on the lower than expected yields of leaf protein when laboratory procedures are upscaled to preparative operations (2). Some of the reports of low yields could have resulted from processing losses caused by inadequate extraction or by failure to use appropriate machinery for the process. The seasonal variability in leaf protein content of typical cultivars has also been a major cause for concern. Since this phenomenon appears to be associated with normal plant development, it seemed reasonable to consider treatment with exogenous agents for changing metabolic processes so as to maintain more constant protein levels. This paper describes the effects of foliar application with putative growth stimulants in combination with the screening of tobacco varieties for leaf protein yields. The rationale for tobacco leaf protein processing has been discussed elsewhere $(3,4,5)$.

Treatments with long-chain aliphatic alcohols or acids as foliar sprays to enhance plant growth have been described $(6,7)$. One of the substances, Triacontanol, has been reported to increase soluble protein in addition to stimulating plant growth (8). Although other researchers have failed to repeat some of the Triacontanol results, RIES and coworkers have explained inconsistencies in the results as due to inadequate formulation or inactivation of Triacontanol by plastic sprayer parts (9). Preliminary greenhouse trials with Triacontanol (10) suggested that the compound did improve protein yields from tobacco leaves in our processing system and initial results also hinted that flower formation might be delayed. Since delay in flowering by growth regulators has been used to enhance sugar production in sugarcane by extending the vegetative stage (11), this result encouraged full scale field experiments. Triacontanol was tested along with another compound, AgroLizer ${ }^{\text {TM }}$, a commercially available product that was claimed to be a growth stimulant in a wide range of plants (7). Foliar applications of Triacontanol and AgroLizer ${ }^{\mathrm{TM}}$ on tobacco were evaluated with respect to their effect on plant behavior, growth rates, and cured leaf yields as well as leaf protein fractionation. Common Maryland type tobacco cultivars and several varieties from the U.S. Department of Agriculture Tobacco Introductions collection were included in the experimental plots. Data on cured leaf yields were also collected from a flue-cured tobacco cultivar, NC-95, grown in North Carolina.

\section{EXPERIMENTAL}

\section{Plant Material}

Plants were grown in the field at two farm locations. A mass planting of MD 201, a late maturing Maryland type cultivar was grown at the Southern Maryland Research and Education Center near Upper Marlboro and sampled periodically for leaf protein production. Plants were set at a row spacing of $50 \mathrm{~cm}$ with $30.5 \mathrm{~cm}$ between rows providing a density of 60000 plants per hectare. In addition, twenty selected genotypes from the U.S. Department of Agriculture T.I. collection were grown at the Beltsville Agricultural Research Center to determine their potential usefulness in the protein extraction process. Agronomic data for the T.I.'s has been compiled by CHAplin and coworkers (12). The first year selections were made at random but in the second year varieties were chosen on the basis of their alkaloid content according to data published by Sisson and SAUnders (13). Both high and low alkaloid varieties were used as well as those differing in nicotine/nornicotine ratio. The T.I.'s were grown under conventional field conditions for Maryland tobacco.

\section{Chemical Treatments}

Triacontanol and AgroLizer ${ }^{\mathrm{TM}}$ - calcium chloride crystals impregnated with a thin film of tetracosanoic acid $(\mathrm{C}=24)$ - were sprayed on the foliage of young tobacco plants two weeks after transplanting to the field. Details with regard to formulation and application recommendations were followed according to suggestions of the suppliers (Table 1). In all cases, comparable blocks of untreated plants served as controls. 
Table 1.

Putative plant growth stimulants.

Triacontanol (straight chain $\mathrm{C}_{30}$ fatty alcohol)

\begin{tabular}{ll}
\hline Formulation: & $\begin{array}{l}\text { Suspension of sodium tallow alkyl sulfate } \\
\text { and Triacontanol dispersed in water }\end{array}$ \\
Application rate: & $500 \mathrm{ng} / \mathrm{l}$ \\
Application mode: & $\begin{array}{l}\text { Drench sprayed on foliage of young } \\
\text { plants (4-5 leaf stage) }\end{array}$ \\
Application note: & $\begin{array}{l}\text { Metallic (non-plastic) sprayer; applied in } \\
\text { midafternoon }\end{array}$ \\
\hline
\end{tabular}

Agrolizer ${ }^{\mathrm{TM}}\left(\mathrm{CaCl}_{2}\right.$ and straight chain $\mathrm{C}_{24}$ fatty acid)

Formulation: $\quad \mathrm{CaCl}_{2}$ surface coated with film of tetracosanoic acid dissolved in water

Application rate: $1.5 \mathrm{~g} / \mathrm{l}$

Application mode: Drench sprayed on foliage of young plants (4-5 leaf stage)

Application note: Plastic sprayer; applied in early morning

\section{Leaf Harvest and Preparation}

Harvesting commenced seven days after chemicals were applied. Plants were periodically cut down at ground level and fresh weights of stalks as well as leaves were recorded. At each interval 20 plants were harvested in duplicate throughout the sampling period, except during the last two weeks when 20 plants were harvested in triplicate. After stripping the leaves from the stalk of five representative plants, $1.5 \mathrm{~kg}$ to $2.0 \mathrm{~kg}$ of homogenate were prepared by maceration in an extrusion grinder. No process water was added but a mixture of dry $\mathrm{NaOH}$ (at $0.6 \mathrm{~g} / \mathrm{kg}$ ) and sodium metabisulfite (at $3 \mathrm{~g} / \mathrm{kg}$ ) was metered into the hopper to retard browning and to maintain the $\mathrm{pH}$ above 5.5 (1). Protein extraction was conducted for the first four weeks although yield data were collected for an additional two weeks thereafter.

\section{Leaf Fractionation}

The green fiber and green fluid fractions were separated by squeezing $100 \mathrm{~g}$ of the pulp through a nylon bag filter with an electrically driven Norwalk ram press. Samples of whole leaf and the dewatered fiber were either dried in an oven at $60^{\circ} \mathrm{C}$ (leaf) or with a Labline fluidized bed drier (fiber) for later analysis. The green fluid which typically comprised $90 \%$ of the initial leaf weight was divided into three portions. One portion was heated immediately to $80{ }^{\circ} \mathrm{C}$ in order to precipitate the total extractable protein. The second portion was warmed to $50{ }^{\circ} \mathrm{C}$ in a water bath and centrifuged at $10000 \times \mathrm{g}$ for 30 minutes. The third portion was acidified to 5.0 with a solution of $50 \%$ citric acid and centrifuged at $1400 \times \mathrm{g}$ for 30 minutes. The clear brown supernatants from these two latter preparations were heated to $80^{\circ} \mathrm{C}$ and centrifuged at $1400 \times \mathrm{g}$ for 10 minutes. These successive steps produced 5 protein concentrates - three green and two off-white in color. One of the objectives of this procedure was to compare the relative effectiveness of heat and acidification to separate the green chlorophyll-protein fraction from the soluble or "white" protein fraction. All pellets were oven dried overnight at $60^{\circ} \mathrm{C}$ and stored in ziplock bags for later analysis.

\section{Analyses}

Crude protein in dried leaf, fiber, and in the protein concentrates was measured by the Kjeldahl procedure with a Brinkmann digestion/distillation/titration system. Titration of the volatilized ammonia to $\mathrm{pH} 4.0$ with standard acid was used as the endpoint (Sybron/Brinkmann Bulletin \#PB-268). Protein was calculated by multiplying the nitrogen value by the factor 6.25 . Dry weight corrections were made from measurements of percent moisture with a COMPU-TRAC moisture analyser (model 50). In addition to these measurements soluble protein in the clarified extracts was determined at the time of extraction with Coomassie Blue $\mathrm{R}-250$ reagent purchased from BIORAD (14).

\section{Agronomic Information}

In addition to collecting fresh weight data for MD 201 tobacco, plant heights of the T.I. varieties were measured immediately prior to flowering. Tobacco plants typically bolt (undergo rapid stem elongation) shortly before flower formation; therefore, plant heights were measured as a means to assess effects of the chemical treatments on the flowering process. A portion of the MD 201 plants were also grown to full-term under standard cultural practices and air-cured. In a parallel study experimental plots of flue cured type tobacco (NC 95) were grown at the Oxford Tobacco Research Station in North Carolina and sprayed two weeks after transplanting with Triacontanol and AgroLizer ${ }^{T M}$. The plots were harvested when ripe and then flue-cured. The combined weights of the cured leaf were recorded in triplicate and yields were calculated on a kilogram per hectare basis.

\section{RESULTS}

\section{Plant Growth Rates and Productivity}

Tobacco plants (MD 201) from field plots at Upper Marlboro were harvested in duplicate on a twice a week schedule. Total fresh weight was divided by the number of plants harvested and growth increments expressed as average weight per plant per day. During the collection period we noticed that the total fresh weight yields fluctuated from time to time. At the end of the season it was obvious that plants in two areas of the field exhibited 
Figure 1.

Effect of chemical spays on tobacco. Linear regression depicting growth rates in grams/plant/day (fresh weight) for MD 201 tobacco sprayed with two experimental chemicals (N $=2 \times 20$ or $3 \times 20$ ). Standard deviations ranged from $\pm 43.49- \pm 74.03$ for the first date to $\pm 95.18- \pm 181.28$ for the last date of harvest, Regression equations for Site \#1 (C) y $=147.0+$ $4.68 \times$, (A) $y=121.7+5.72 x$, (T) $y=180.8+5.50 x$ and for Site $\# 2$ (C) $y=179.8+7.53 x$, (A) $y=116.0+10.63 x$, (T) $y=191.2+$ $7.89 \times ;\left(C=\right.$ Control, $\mathrm{A}=$ AgroLizer $^{\mathrm{TM}}, \mathrm{T}=$ Triacontanol .
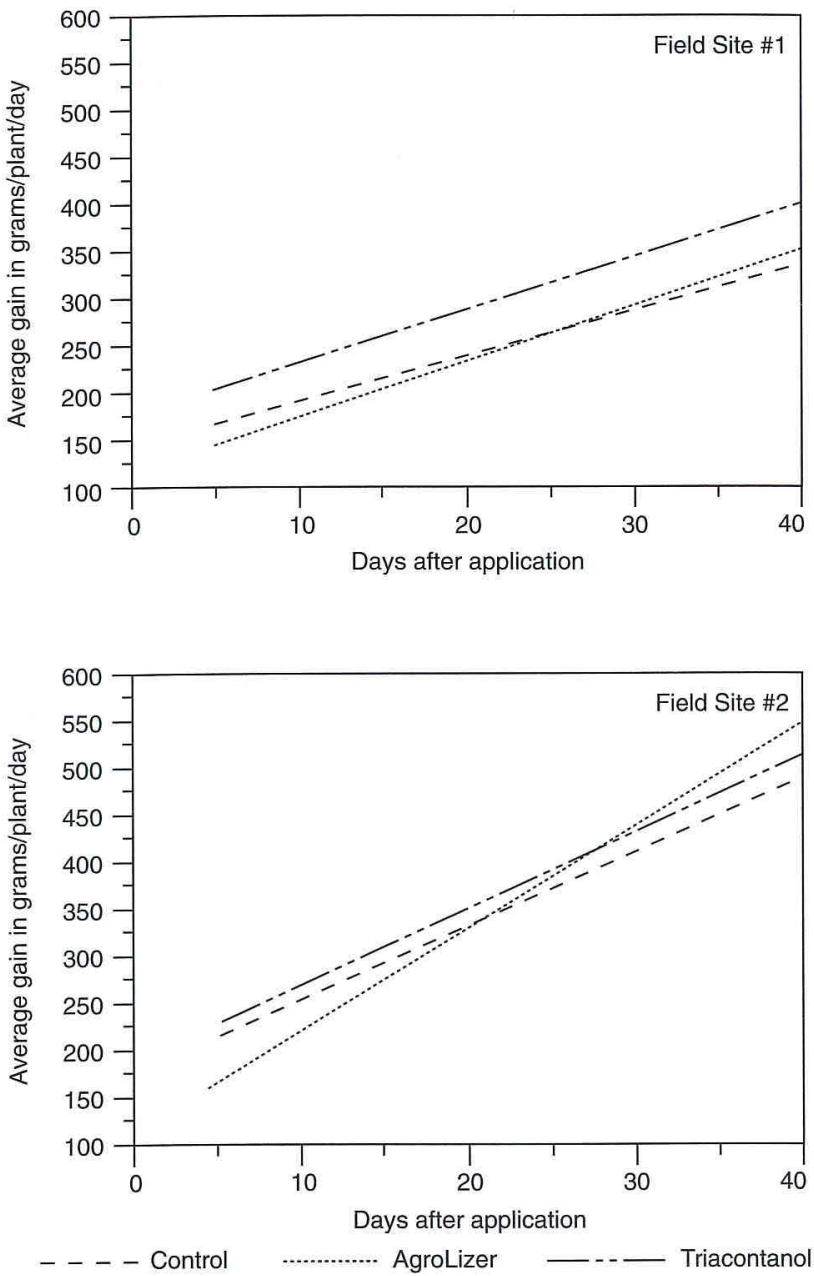

different growth rates. The growth dissimilarities were apparently due to differences in soil types. An unusually dry summer caused severe drought stress at one of the locations. According to the day-to-day yield data the growth curve of plants at Site \# 1 was clearly different from that of Site \#2 (Figure 1). At both locations an early stimulation of growth occurred in plants sprayed with Triacontanol. However, the plants treated with AgroLizer $^{\mathrm{TM}}$, at Site \#2, eventually grew larger than either control or Triacontanol treated plants (Figure 1). In order to determine whether these treatments affected cured leaf yield, two experimental plots at different geographical locations under conventional spacing and cultural conditions were grown to maturity. As shown in Table 2, the cured weights of all three sets of plants grown at the
Table 2.

Cured tobacco leaf yields from two locations as affected by foliar spray treatments.

\begin{tabular}{l|c|c}
\hline & $\begin{array}{c}\text { MD } \\
\mathrm{kg} / \mathrm{ha}\end{array}$ & $\begin{array}{c}\mathrm{NC} \\
\mathrm{kg} / \mathrm{ha}\end{array}$ \\
\hline Control & $2532.75 \pm 100.78$ & $2940.75 \pm 197.53$ \\
AgroLizer & $2625.75 \pm 249.81$ & $3159.00 \pm 99.89$ \\
Triacontanol & $2632.11 \pm 244.24$ & $2983.50 \pm 380.104$ \\
LSD (0.05) & 419.43 & 507.39 \\
\hline
\end{tabular}

Maryland location differed marginally with both AgroLizer $^{\mathrm{TM}}$ and Triacontanol treated plants surpassing the controls by only $3.7 \%$ and $3.9 \%$, respectively. With flue-cured plants grown in North Carolina, treatment with AgroLizer ${ }^{\mathrm{TM}}$ resulted in a slightly better $7.5 \%$ gain. Although the yield increases resulting from chemical treatments were suggestive, they were not significant because of wide variations among the plants in each subplot.

\section{Protein Concentration in Nonprocessed Leaves}

Kjeldahl determinations of total crude protein in freshly harvested tobacco leaves revealed protein oscillation patterns that were reminiscent of those we described previously (1). However, because the sampling was not done as frequently as in the earlier study, the profiles shown in Figure 2 are not as definitive. Nevertheless, the graph

\section{Figure 2.}

Total protein in tobacco leaves. Effect of chemical foliar spray. Percentage of total leaf protein in treated and control plants (MD 201) harvested twice a week for one month. Each point on the graph is the mean of three measurements of duplicate field samples. Note particularly the disparity between AgroLizer ${ }^{\mathrm{TM}}$ treated plants and control or Triacontanol treated plants on day 14 .

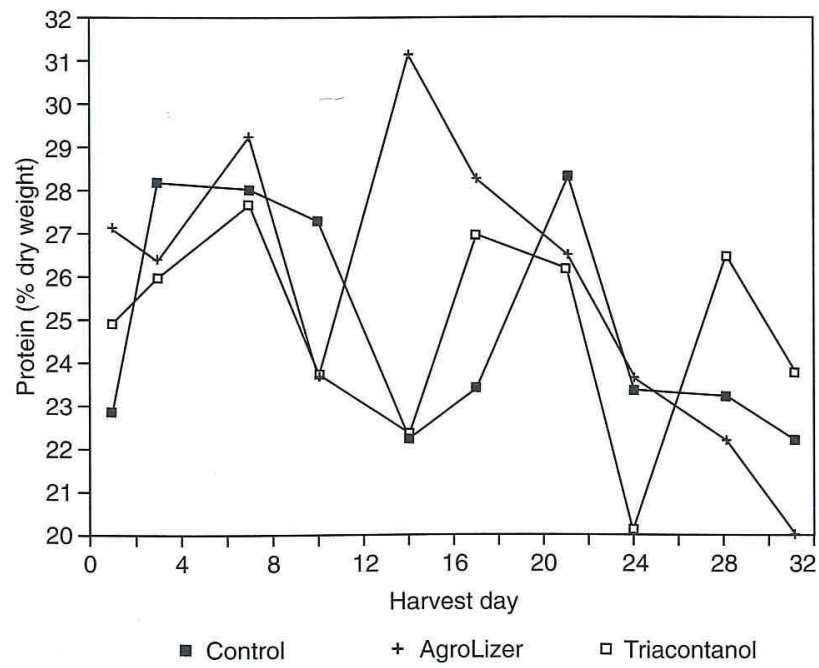


demonstrates that the total protein in tobacco leaves varies by as much as 30\% during the growing season. It appears that both chemical treatments shifted the leaf protein profile somewhat, but not in the same manner. The most amazing shift was the midseason maximum observed in AgroLizer ${ }^{\mathrm{TM}}$ treated plants which corresponded to a minimum point for controls and Triacontanol treated plants (35 days after transplanting).

\section{Protein Concentration in Leaf Extracts}

During the course of initial greenhouse experiments with Triacontanol and AgroLizer ${ }^{\mathrm{TM}}$, a positive response to the two chemicals was often observed. For example, whereas one variety (T.I. 1243) produced up to $5 \mathrm{mg} / \mathrm{ml}$ of soluble protein and another variety (T.I. 170) produced only half as much, extracts from both tobacco types contained the most protein when treated with AgroLizer ${ }^{\mathrm{TM}}$ and the least when untreated (Table 3). In follow-up field studies the levels of soluble white protein were not consistently higher in leaves from treated plants although early in the growing season somewhat more leaf protein was obtained from the leaves of AgroLizer ${ }^{\mathrm{TM}}$ treated plants (Figure 3). It was also observed that the extracted protein profiles did not match the total protein in unextracted leaves, indicating the amount of soluble protein that can be obtained is not solely an intrinsic property of the original protein content in the leaf. Of the two methods for removing the green fraction from the extract prior to precipitating the soluble protein, it was found that lowering the $\mathrm{pH}$ to 5.0 resulted in poorer protein recoveries than a $50{ }^{\circ} \mathrm{C}$ treatment (Figure 4). The data show only the values obtained with extracts from control plants, although the results with chemically treated plants were similar. The major advantage in acidification was that low speed centrifugation was sufficient to clarify the extract whereas a $50^{\circ} \mathrm{C}$ treatment required high speed centrifugation.

\section{Purity of Protein Precipitates}

Previous work had indicated that the purity of protein precipitates obtained from tobacco leaf extracts can vary considerably (1). These results were substantiated by the present study wherein three green and two white pellets were analyzed for percent protein. Although the protein

Table 3.

Protein extraction as affected by foliar spray treatments.

\begin{tabular}{l|c|c}
\hline & Treatment & $\begin{array}{c}\text { Protein } \\
(\mathrm{mg} / \mathrm{ml})\end{array}$ \\
\hline & T.I. 170 & T.I. 1243 \\
Control & $1.08 \pm 0.88 \mathrm{a}^{*}$ & $3.99 \pm 0.72 \mathrm{a}$ \\
AgroLizer & $2.74 \pm 0.90 \mathrm{~b}$ & $5.12 \pm 0.91 \mathrm{a}$ \\
Triacontanol & $1.92 \pm 1.19 \mathrm{a}$ & $4.29 \pm 0.13 \mathrm{a}$ \\
LSD $(0.05)$ & 1.99 & 1.35 \\
\hline
\end{tabular}

"Means having common letters within a column are not significantly different at the 0.05 probability level based on the t-test.
Figure 3.

Total protein in tobacco leaf extracts. Effect of chemical foliar spray. Amount of soluble "white" protein in leaf extracts from field grown tobacco plants (MD 201) during one month sampling period. Very little difference was observed in protein levels among the three groups. All measurements were made in triplicate from duplicate field samples.

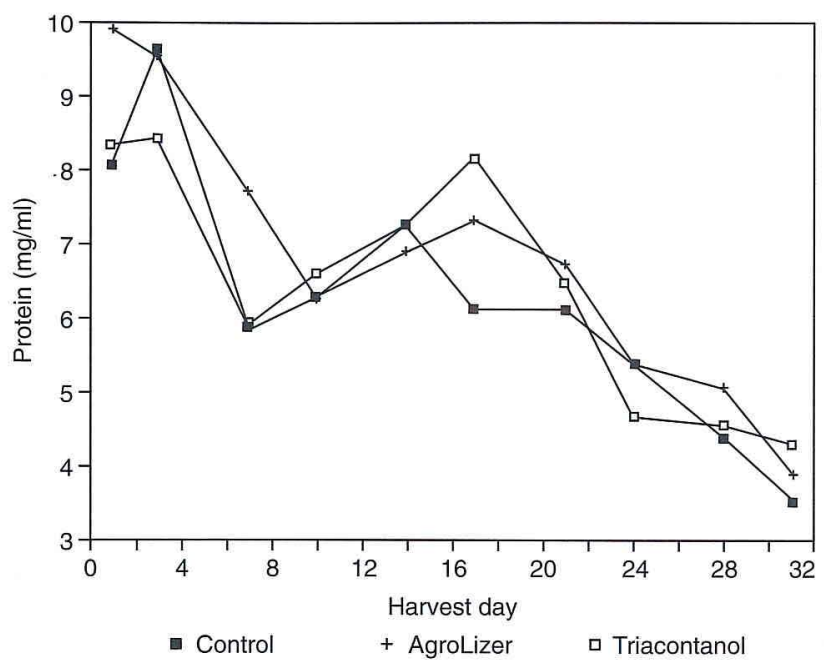

content in the unfractionated precipitate (data not shown) peaked 5 weeks after transplanting (harvest day 14) for all three sets of plants, it did not coincide with the peak for protein concentration (cf. Figure 3). Comparisons of protein purity in green and white pellets fractionated by acidification or heat are given in Figures 5 and 6, respectively. The purity of the white pellets obtained after heat fractionation was usually higher than with acid fractionation. Frequently, though not invariably, the percent protein value was highest with AgroLizer ${ }^{\mathrm{TM}}$ treated

\section{Figure 4.}

Tobacco leaf protein extraction. Removal of green fraction. Comparison of amount of "white" protein in leaf extracts fractionated with either $50^{\circ} \mathrm{C}$ heat treatment followed by high speed centrifugation or acidification to $\mathrm{pH} 5.0$ with $50 \%$ citric acid followed by low speed centrifugation. Only results with control plants are shown.

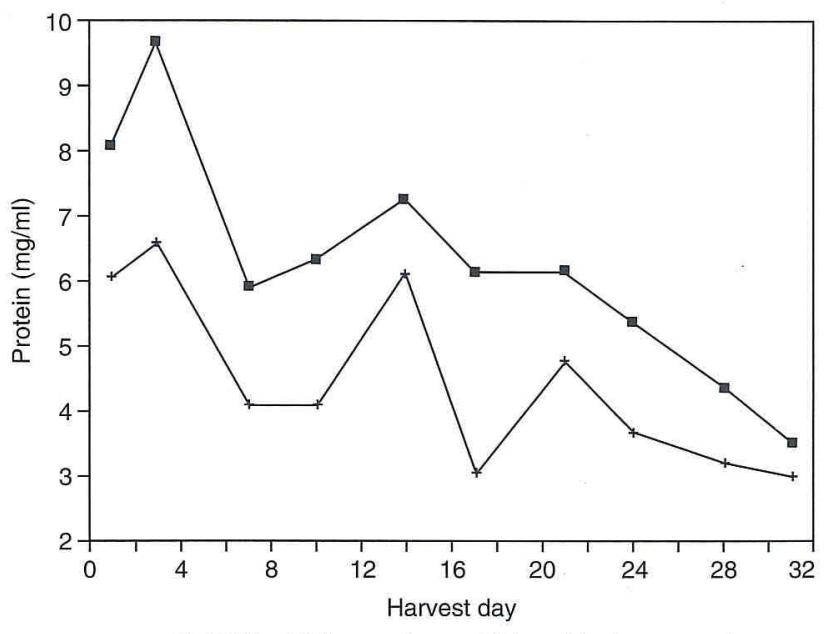

- $50^{\circ} \mathrm{C}+$ High speed + Citric acid + Low speed 
plants. Neither Triacontanol nor AgroLizer ${ }^{\mathrm{TM}}$ uniformly increased the level of protein purity in the concentrates.

\section{Varietal Difference in Leaf Protein Extraction}

Data on protein extraction from six tobacco genotypes are summarized in Figure 7. These plants were harvested for extraction approximately two weeks prior to flowering which meant harvesting the early flowering varieties first. Leaf protein yields associated with the spraying of plants with either Triacontanol or AgroLizer ${ }^{\text {TM }}$ were confounded by genetic factors. This was especially evident in two of the varieties, i.e. T.I. 500 and T.I. 1478. With the former the highest leaf protein yields occurred with AgroLizer $^{\mathrm{TM}}$, whereas with the latter superior results were seen with Triacontanol. Among the varieties screened, T.I. 401 produced by far the most soluble protein irrespective of treatment. Furthermore, it was found that extractable leaf protein still ranged from $8-12 \mathrm{mg} / \mathrm{ml}$ at a second harvest 20 days later when T.I. 401 plants were in full flower in spite of a perceptible drop in total protein levels.

\section{Effect of Chemical Treatments on Flowering}

Tobacco genotypes vary widely in their heights as well as in their maturation rates (12). A sudden, rapid elongation of the stem is indicative of floral initiation. Preliminary greenhouse screening had suggested that Triacontanol delayed flowering in tobacco resulting in taller plants with six more leaves but not all varieties responded in the same manner (10). Field experiments were designed to investigate this phenomenon by measuring plant heights when the first terminal bud appeared. The results are given in
Table 4. Five of the twenty varieties were already flowering when measurements began. Of these five, two exhibited delayed flowering associated with Triacontanol treatment. Among the remaining fifteen, seven were significantly shorter in the Triacontanol plots when measurements commenced. Six varieties showed no effect, whereas one appeared to be inversely affected by Triacontanol (i.e. the plants were taller). The pattern for AgroLizer $^{\mathrm{TM}}$ treated plants was much different with at least three varieties showing significantly taller plants as a result of treatment. It was clear from these data that the effect on flowering presumably induced by Triacontanol is highly specific for genotype and probably interacts with environmental conditions. Kasperbauer (15) has reported that exposure to cool nights and short photoperiods during early stages of growth can stimulate premature tobacco flowering with a consequent stunting of vertical plant development.

\section{DISCUSSION}

The work described here is a continuation of research conducted over a number of years on the feasibility of extracting leaf protein as a by-product of tobacco processing. Previous investigations (up to pilot-plant scale) have demonstrated that tobacco leaf protein production was compatible with homogenized leaf curing (HLC) and technically feasible (4). It is now obligatory to deal with certain practical difficulties that could hinder implementation of the system. One set of problems associated with leaf protein extraction is agronomic in nature (as distinguished from mechanical, i. e. engineering factors). To be commercially acceptable leaf protein production must be reliable. Experience gained during the past decade has

Table 4.

Effect of chemical sprays on tobacco development. Plant heights prior to flowering.

\begin{tabular}{lc|c|r|r}
\hline T.l./Nariety & $\begin{array}{c}\text { Control } \\
\text { Heights }(\mathrm{cm})\end{array}$ & $\begin{array}{c}\text { AgroLizer } \\
\text { Heights }(\mathrm{cm})\end{array}$ & $\begin{array}{c}\text { Triacontanol } \\
\text { Heights }(\mathrm{cm})\end{array}$ & LSD (0.05) \\
\hline T.I. 102 & $155.44 \pm 15.43$ & $143.25 \pm 18.64^{*}$ & $144.70 \pm 14.43^{*}$ & 10.86 \\
T.I. 301 & $131.96 \pm 5.81$ & $126.10 \pm 7.79^{*}$ & $109.89 \pm 11.88^{*}$ & 5.89 \\
T.I. 330 & $117.13 \pm 8.46$ & $121.55 \pm 9.10$ & $110.32 \pm 10.00^{*}$ & 5.97 \\
T.I. 385 & $119.68 \pm 7.09$ & $122.43 \pm 8.46^{*}$ & $102.43 \pm 11.38^{*}$ & 6.09 \\
T.I. 437 & $140.79 \pm 7.10$ & $149.75 \pm 12.91^{*}$ & $134.65 \pm 14.15$ & 8.05 \\
T.I. 439 & $128.00 \pm 4.76$ & $130.93 \pm 7.64$ & $118.41 \pm 7.08^{*}$ & 4.40 \\
T.I. 865 & $117.72 \pm 10.29$ & $136.11 \pm 16.31^{*}$ & $140.64 \pm 14.35^{*}$ & 9.54 \\
T.I. 995 & $124.67 \pm 8.96$ & $115.40 \pm 15.39^{*}$ & $128.43 \pm 11.72$ & 8.21 \\
T.I. 1095 & $138.74 \pm 10.12$ & $130.93 \pm 19.52$ & $119.07 \pm 25.18^{*}$ & 13.27 \\
T.I. 1349 & $138.39 \pm 15.70$ & $129.39 \pm 12.31^{*}$ & $112.46 \pm 17.55^{*}$ & 10.99 \\
T.I. 1457 & $119.24 \pm 8.74$ & $111.00 \pm 13.40^{*}$ & $116.79 \pm 7.49$ & 6.76 \\
T.I. 1499 & $138.80 \pm 9.75$ & $123.74 \pm 14.81^{*}$ & $134.33 \pm 10.77$ & 8.08 \\
T.I. 1594 & $126.44 \pm 16.40$ & $133.72 \pm 20.65$ & $129.07 \pm 11.06$ & 11.96 \\
MD Mammoth & $118.44 \pm 7.26$ & $112.03 \pm 6.82^{*}$ & $116.47 \pm 7.19$ & 4.65 \\
BUR. Mammoth & $142.44 \pm 9.69$ & $142.83 \pm 20.29$ & $138.00 \pm 12.83$ & 10.01 \\
X & 130 & 128 & & \\
\hline
\end{tabular}

* Denotes treatment significantly different from control at $\leqq 0.05$ probability level based on t-test. 
provided ample evidence that protein production from tobacco leaves is highly variable and unpredictable under field conditions.

These considerations have led to an examination of the changes that occur in leaf protein content and extractability during growth and development of tobacco plants grown out-of-doors. In the present study we investigated several aspects of leaf protein yield and recovery after plants were chemically treated. The chemicals we chose for the study were experimental in the sense that their effectiveness for this purpose had not been previously established in field trials although initial results of smallscale experiments under greenhouse conditions had indicated a positive response. The growth promotive activity of Triacontanol, a 30-carbon straight chain fatty alcohol, has been described in numerous publications by REIs and coworkers $(6,16,17,18)$. An interesting result of these studies was that application of the chemical increased soluble protein levels (8). Other investigators have reported inconsistent results with Triacontanol (19). The formulation we used was that recommended by LAUGHLIN and coworkers (20) and in fact was supplied in sealed vials to us by REIS as a stock suspension at $10 \mu \mathrm{g} / \mathrm{ml}$. The other chemical used in our research, viz., AgroLizer ${ }^{\mathrm{TM}}$, is a proprietary combination of calcium chloride and tetracosanoic acid. According to the supplier, AgroLizer ${ }^{\mathrm{TM}}$ stimulates plant growth similar to the effect of Triacontanol except that it showed more consistent results in experimental plots (WELEBIR, personal communication). While the full season study of final cured leaf weights did show marginal gains in yield with both chemicals, the increases were not statistically significant. It is possible that the amount and timing of the spray applications were not sufficiently above a minimal threshold level needed for efficacy. While no major advantage in utilizing either chemical in the leaf protein extraction process could be deduced from the data, there was some evidence that AgroLizer ${ }^{\mathrm{TM}}$, in particular,

\section{Figure 5.}

Purity of leaf protein concentrates fractionated by acidification. Upper set of points show percentage protein in "white" fraction; lower set of points are for green fraction removed in previous step. Lines drawn between points for control only.

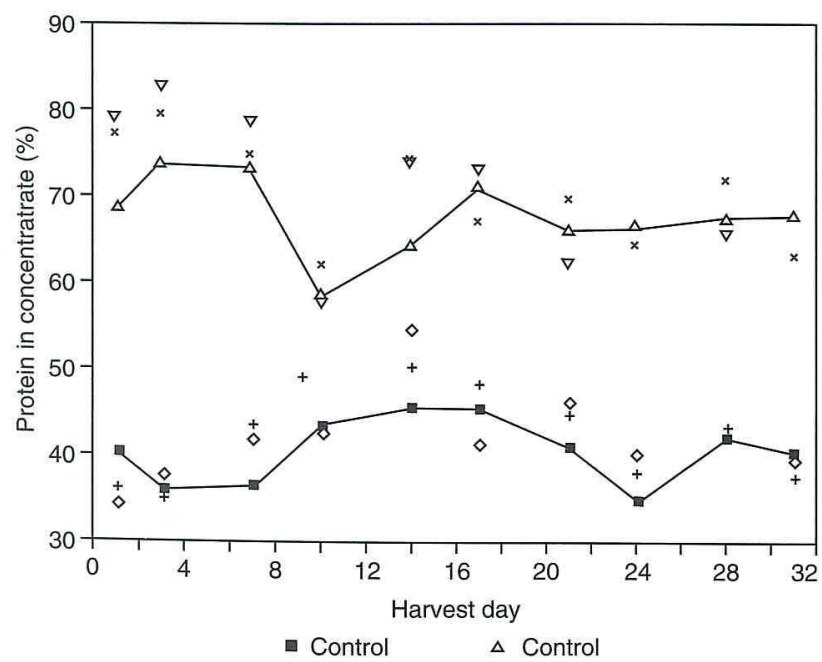

Figure 6.

Purity of leaf protein concentrates fractionated by heat. Upper set of points show percentage protein in "white" fraction; lower set of points are for green fraction removed in previous step. Lines drawn between points for controls only.

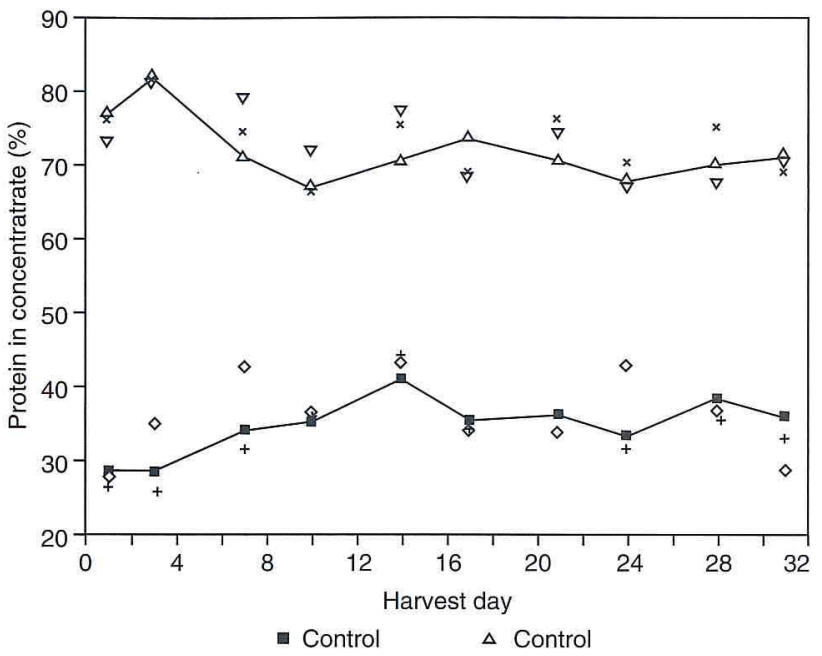

altered protein fractionation. For example, there was a discernible though minor improvement in the purity of protein in acid or heat fractionated precipitates that appeared to be associated with AgroLizer ${ }^{\mathrm{TM}}$ treatment (see Figures 5 and 6). None of the three major parameters in protein recovery, i.e. total leaf protein content, leaf protein fractionation, or the purity of leaf protein isolates were improved consistently.

Growth regulators have proved to be useful in a number of cropping situations and it is conceivable that a chemical or combination of chemical ingredients may be discovered that will improve the dependability of leaf protein extraction. The use of plant growth regulators to alter leaf

\section{Figure 7.}

Tobacco leaf protein extraction. Comparison of amount of "white" protein in leaf extracts from tobacco varieties sprayed with two experimental chemicals. Varieties numbered as follows: $1 .=$ T.I. $-1410 ; 2 .=$ T.I.-666; 3. = T.I.-401; 4. = T.I. $-500 ; 5 .=$ T.I.-1478; 6. = T.I.-1365.

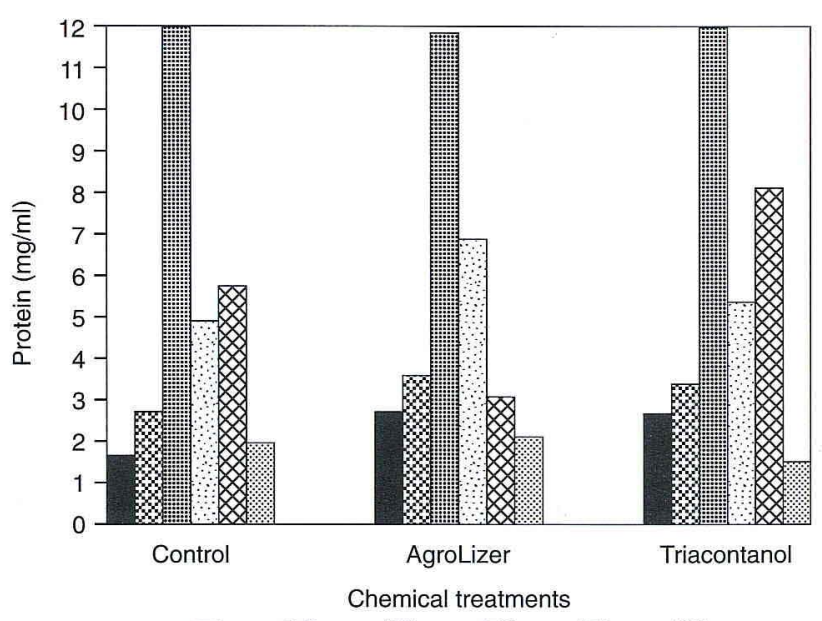

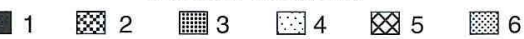


protein characteristics is not without precedent. KUNG and coworkers (21) reported that application of $1 \mathrm{mg} / \mathrm{l}$ of authentic plant hormones (indole-acetic acid and kinetin) to tobacco seedlings grown on agar medium caused a dramatic reduction in free 705 ribosomes as well as in the chloroplastic enzyme ribulose 1-5 bisphosphate carboxylase/oxygenase, viz. Fraction 1. The appearance of specific stress-inducible proteins in plant cells detectable by electrophoresis as a response to salt stress $(22,23)$ or heat shock (24) is well documented. These proteins invariably decline or disappear entirely when the stress is removed. In experiments described here, the likelihood of a stress-type response is slight since the amount of chemical applied to each tobacco plant was vanishingly small (see Experimental). The objective was to evaluate claims that single small doses of Triacontanol and AgroLizer ${ }^{\mathrm{TM}}$ acting as growth regulators altered growth and protein accumulation under field conditions throughout the season.

Previous studies on growing closely spaced tobacco in order to increase the production of green leaf matter per unit area $(25,26)$ have not adequately addressed the problem of fluctuating leaf protein content associated with seasonal aspects of tobacco development (1). One cannot hope to obtain satisfactory leaf protein yields if all the tobacco must be harvested within a limited timeframe. Harvesting plants for leaf protein during an entire season requires assurance that protein extractability be sustained at optimal levels over an extended period of time. If the metabolic progression in tobacco could be altered so as to stabilize leaf protein levels, the opportunity for successive multiple harvests of leaf protein might be enhanced. The two chemicals tested for this purpose affected plant growth and leaf protein fractionation in subtle ways, but results of the present study were inconclusive.

Since it has been amply demonstrated that widely differing amounts of extractable leaf protein are obtained from different tobacco varieties, it appears that the most direct and expedient means for achieving reliable production of leaf protein is to select and manipulate favorable genotypes for this purpose. This paper documents the original discovery of the best tobacco leaf protein producer found to date - T.I. 401. Its properties related to leaf protein extraction and fractionation are described in more detail in a companion paper.

\section{REFERENCES}

1. De Jong, D. W. and J. A. Saunders: Fluctuations in protein levels of tobacco leaves and consequences for extractability; Beitr. Tabakforsch. Int. 13 (1986) 139-149.

2. Dumery, B., J. P. Albo and J. Chouteau: Analytical approach of tobacco proteins. Technological Implications; Annales du Tabac 17 (1981) 105-132.
3. Tso, T. C.: Tobacco as a potential food source and smoke material; Beitr. Tabakforsch. 9 (1977) 63-66.

4. De Jong, D. W. and J. J. Lam: Application of homogenized leaf curing to protein recovery and to the alteration of leaf chemistry for production of less hazardous tobacco; Tob. Res. 5 (1979) 1-27.

5. Wildman, S.: An alternative use for tobacco agriculture: proteins for food plus a safer smoking material. Plants - the potentials for extracting protein, medicines, and other chemicals; OTA (1983) 63-67.

6. Reis, S. and R. Houtz: Triacontanol as a plant growth regulator; Hort. Sci. 18 (1983) 654-662.

7. Welebir, A. J.: Novel crop yield enhancing formulations containing fatty acids and calcium; Biochemical Marketing Corporation Bulletin, 1983.

8. Reis, S. and V. Wert: Rapid effects of triacontanol in vivo and in vitro; J. Plant Growth Regul. 1 (1982) 117-127.

9. Maugh, T. H.: Mystery of triacontanol's inconsistency may finally have been solved; Science 212 (1981) 33-34.

10. De Jong, D. W.: Response of tobacco plants to treatment with 1-triacontanol (1-hydroxycontane); Proceedings of the 37th Tobacco Chemists' Research Conference (1983) 16.

11. Nickell, L. G.: Plant growth regulators in the sugar cane industry; in: Chemical manipulation of crop growth and development, edited by J. S. McLaren, 1982, pp. 167-189.

12. Chaplin, J. F., J. R. Stavely, C. C. Litton and G. W. Pittarelli: Catalog of the Tobacco Introductions in the USDA's tobacco germplasm collection (N. tabacum); USDA/ARS Agricultural Reviews and Manuals S-27, 1982.

13. Sisson, V. A. and J. A. Saunders: Tobacco Germplasm Collection: Suppl. 1. Alkaloid content of the cured leaf; USDA/ARS Agricultural Reviews and Manuals S-27, 1983.

14. Bradford, M. M.: A rapid and sensitive method for the quantitation of microgram quantities of protein utilizing the principle of protein dye binding; Anal. Biochem. 72 (1976) 248-254.

15. Kasperbauer, M. J.: Interaction of photoperiod and temperature on flowering of Burley tobacco $(N$. tabacum); Tob. Sci. 10 (1966) 119-120.

16. Reis, S., V. F. Wert and J. A. Biernbaum: Factors altering response of plants to triacontanol; Hort. Sci. 108 (1983) 917.

17. Reis, S., V. F. Wert and J. A. Biernbaum: Interference of triacontanol activity by constituents present in experimental and field sprayers; Hort. Sci. 109 (1984) 145.

18. Reis, S.: Regulation of plant growth with triacontanol; CRC Critical Reviews in Plant Sciences 2 (1985) 239-285.

19. Steffens, G. L. and J. F. Worley: Triacontanol. Evaluation in several plant assays; Proceedings of the Plant Growth Regulator Workshop, Dallas, TX, July $12-15,1980$. 
20. Laughlin, R. G., R. L. Munyon, S. Reis and V. F. Wert: Growth enhancement of plants by femtomole doses of colloidally dispersed triacontanol; Science 219 (1983) 1219-1221.

21. Kung, S. D. and T. C. Tso: Tobacco as a potential food source and smoke material: Soluble protein content, extraction, and amino acid composition; J. Food Sci. 43 (1978) 1844-1847/52.

22. Ericson, M. C. and S. H. Alfinito: Proteins produced during salt stress in tobacco cell culture; Plant Physiol. 74 (1984) 506-509.

23. Singh, N. K., A. K. Handa, P. M. Hasegawa and R. A. Bressan: Proteins associated with adaptation of cultured tobacco cells to NaCl; Plant Physiol. 79 (1985) 126-137.

24. Key, J. L., C. Y. Lin and Y. M. Chen: Heat shock proteins of higher plants; Proc. Natl Acad. Sci., USA 78 (1981) 3526-3530.

25. Woodlief, W. G., J. F. Chaplin, C. R. Campbell and D. W. De Jong: Effect of variety and harvest treatments on protein yield of close-grown tobacco; Tob. Sci. 25 (1981) 83-86.
26. Bernstein, B. A., R. H. Lowe and S. J. Sheen: Biomass and protein yield of tobaccos grown at three plant densities; Tob. Res. 8 (1982) 1-12.

\section{Acknowledgements}

The author gratefully acknowledges the expert technical assistance of Samuel Garrett, Denise Ardolini, Bruce Cweiber, Mike Kouchakdjian and Bill West during the course of these investigations.

Author's address

Crops Research Laboratory,

U.S. Department of Agriculture,

Agriculture Research Service,

Oxford, North Carolina, 27565, U.S.A. 